\title{
Study of the Behavior of Floating Stone Columns in Soft Clay Formations Using Numerical Modeling
}

\author{
Ayman L. Fayed ${ }^{1}$, Tamer M. Sorour ${ }^{1}$, and Hany F. Shehata ${ }^{2(\bowtie)}$ \\ ${ }^{1}$ Structural Engineering Department, Ain-Shams University, \\ Abbasseya, Cairo, Egypt \\ \{ayman_fayed, tamer.sorour\}@eng.asu.edu.eg \\ ${ }^{2}$ Housing and Building National Research Center (HBRC), Dokki, Giza, Egypt \\ hf.shehata@yahoo.ca
}

\begin{abstract}
Stone columns have been increasingly acknowledged as one of the viable foundation techniques in soft ground conditions. The concept behind this option is to enhance soft soils by insertion of special elements stiffer than the original soil. The stiffness of the improved ground depends on the geometry of the stone columns in addition to the relative stiffness between the original soft soil and the installed elements. Back analysis of case histories is always a successful and reliable approach in studying the in situ behavior of different ground improvement methods. In this paper, a well instrumented case study of floating stone columns installed in the Bothkennar soft clay formation is studied using numerical modeling utilizing the finite elements method. Different soil constitutive models are investigated to define the most appropriate one in simulating the actual Bothkennar soft clay behavior. Results of the comparison between the monitored field performance and the estimated behavior from the numerical model using different constitutive models are presented and discussed, while recommendations for the most suitable stress strain model of the studied clay are concluded.
\end{abstract}

\section{Introduction}

Vibro replacement is a popular form of ground improvement commonly used to enhance the settlement and bearing capacity characteristics of soft soils. Vertical columns of compact stones are formed in the ground using either the top or bottom feed systems. Vibro replacement process typically involves replacing $10-35 \%$ of the in situ soil with crushed stones. The high stiffness properties of the crushed stones reduce the overall and differential settlements of the structures founded on the treated soil. The consolidation time is also reduced due to the high permeability of the crushed stones. Stone columns can be used to provide support for a variety of loading scenarios ranging from small footings (i.e. pads/strip footings) to large area loadings (i.e. embankments and large dimensions slabs).

Design of foundations on soft soils is usually governed by settlement criteria rather than bearing capacity due to the high compressibility characteristics of soft soils. The majority of analytical design methods developed to date contain many simplifying 
assumptions, such as the unit cell concept, which assumes an infinite grid of columns supporting an infinitely wide load area. Therefore, they do not account for the loss of lateral confinement associated with groups of columns supporting small footings. In addition, the reduction in vertical stresses with depth beneath small footings is much sharper than that beneath wide area loadings and, therefore, offers the possibility of partial depth treatment. While some correction factors exist to account for the loss of lateral confinement, current design methods do not consider the loss of lateral confinement for small groups of floating stone columns. While the bearing capacity of small groups of stone columns has been well researched, a lack of information exists regarding the settlement performance of small groups of columns. This is highlighted by McCabe et al. (2009) whose settlement database of over 20 case studies comprised only three cases related to small groups of columns.

\section{Numerical Modelling: Procedures and Discussions}

Many numerical studies conducted to study the behavior of the stone columns are axisymmetric analyses of large groups of columns. The shortage of information regarding the settlement performance of small groups of stone columns was identified by Black (2006) who conducted some high quality laboratory research; however, it is difficult to extrapolate the findings due to scale effects associated with laboratory tests and also as some of the area ratios considered are at the high end of typical values used in practice.

This research aims of studying the behavior of floating small groups of columns using finite element modelling by PLAXIS 3D 2016 for full-scale trial models in Bothkennar soft clay. The effect of the used constitutive laws on the performance of stone columns and the associated ground deformations are also investigated for both treated and untreated soft clay profiles. Lastly, some recommendations to properly simulate the small group of stone columns by numerical modelling in Bothkennar soil profile are provided.

\subsection{Constitutive Models}

Three common constitutive models that have already been implemented in most of the geotechnical finite element codes are used in this research; Mohr-Coulomb Model (MCM), Hardening Soil Model (HSM) and Soft Soil Model (SSM). A brief description of these models is presented below.

\subsubsection{Mohr Coulomb Model (MCM)}

Mohr-Coulomb model as shown in Fig. 1a is an elastic-perfectly plastic model that is often used to model soil behavior and serves as a first-order model. In general stress state, the model's stress-strain behaves linearly in the elastic range, with two defining parameters from Hooke's law (Young's modulus, E and Poisson's ratio, v). There are two parameters define the failure criteria (the friction angle, $\phi$ and cohesion, c) and also a parameter to describe the flow rule (dilatancy angle, $\psi$ which comes from the use of non-associated flow rule which is used to model a realistic irreversible change in 


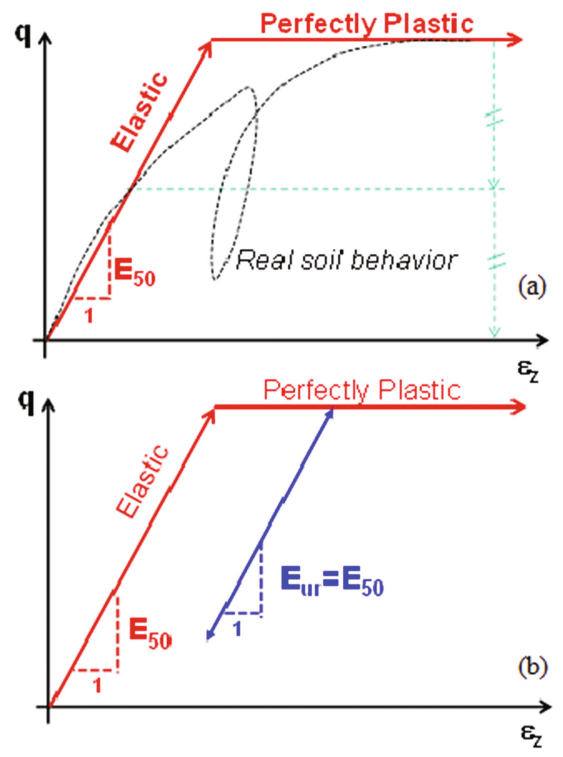

(a) Elastic-perfectly plastic assumption of Mohr-Coulomb constitutive model.

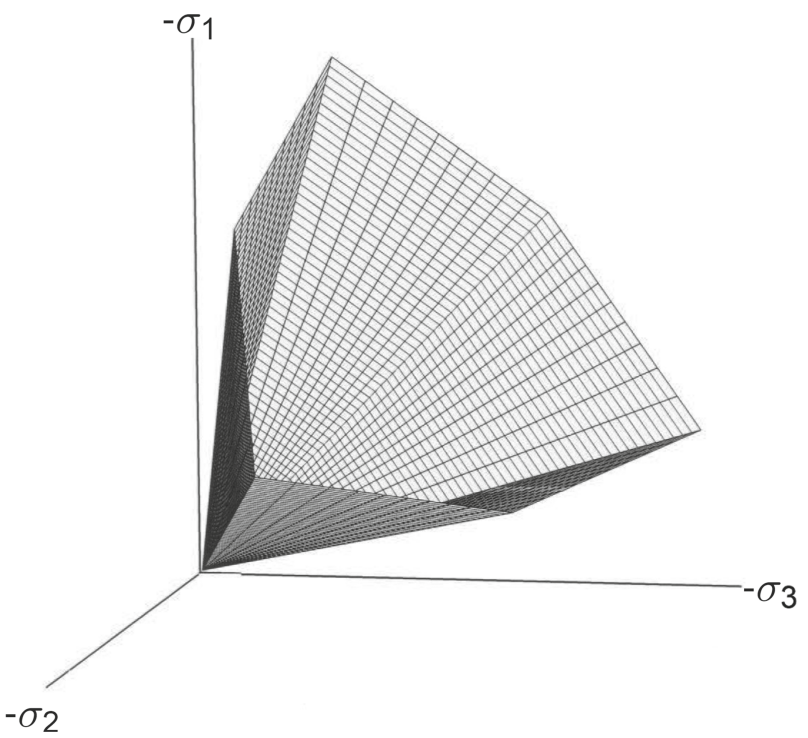

(b) The Mohr-Coulomb yield surface in principal stress space $(c=0)$

Fig. 1. Mohr-Coulomb constitutive model. 
volume due to shearing). Mohr-Coulomb model is a simple and applicable to three-dimensional stress space model, as shown in Fig. 1b, with only two strength parameters to describe the plastic behavior.

\subsubsection{Hardening Soil Model (HSM)}

The Hardening Soil model (Brinkgreve and Vermeer 1997; Schanz 1998) is a true second order model for soils in general, for any type of application (Brinkgreve 2005). The model involves friction hardening to model the plastic shear strain in deviatoric loading, and cap hardening to model the plastic volumetric strain in primary compression. Distinction can be made between two main types of hardening, namely shear hardening and compression hardening. Shear hardening is used to model irreversible strains due to primary deviatoric loading. Compression hardening is used to model irreversible plastic strains due to primary compression in oedometer loading and

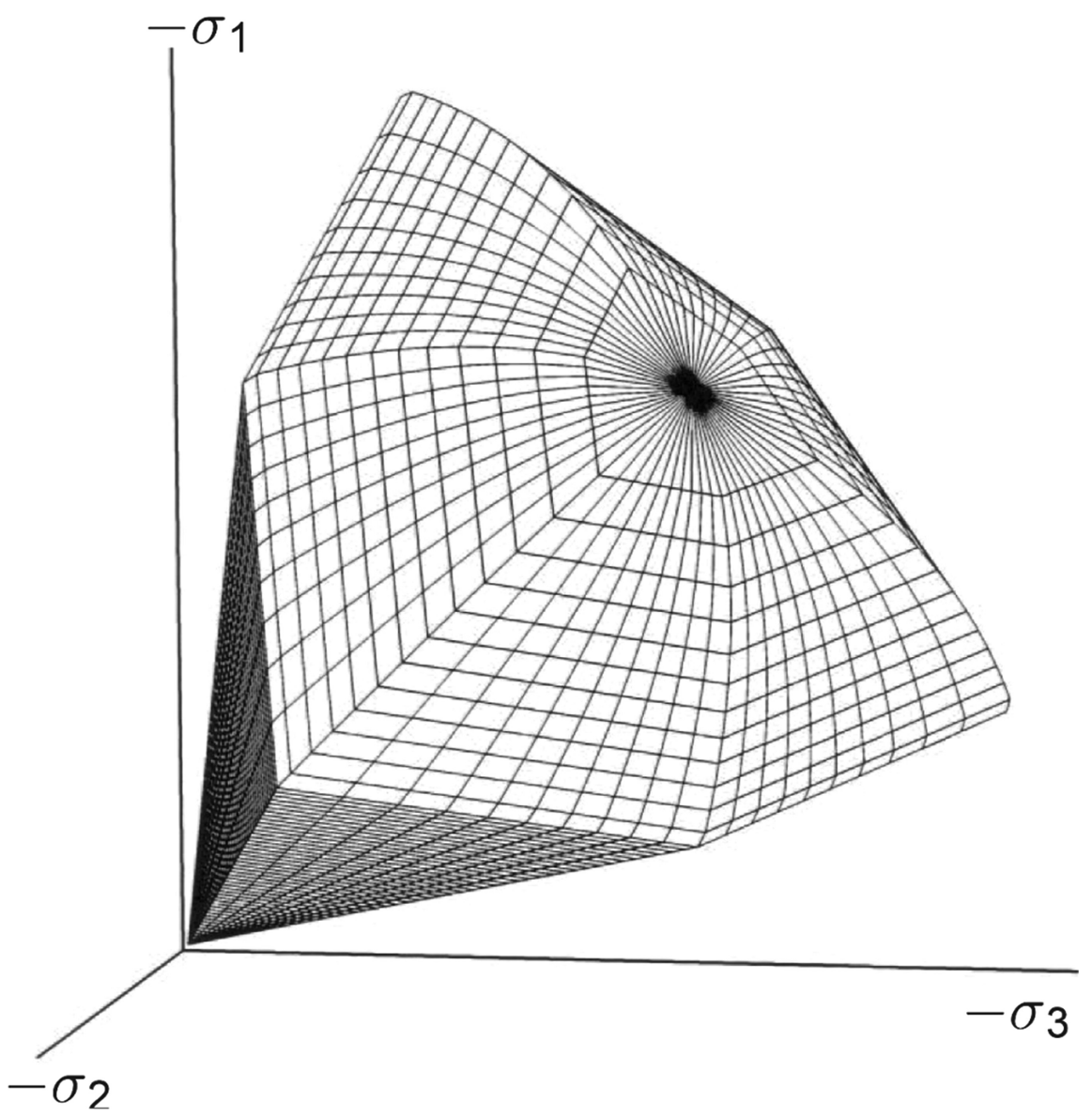

Fig. 2. Total yield contour of the hardening-soil constitutive model in principal stress space for cohessionless soil. 
isotropic loading. Both types of hardening are contained in this model. Yield contour of the model in three-dimensional space is shown in Fig. 2. Failure is defined by means of Mohr-Coulomb failure criterion. Some basic characteristics of the model are Stress dependent stiffness according to a power law (m), plastic straining due to primary deviatoric loading $\left(\mathrm{E}_{50}^{\mathrm{ref}}\right)$, plastic straining due to primary compression $\left(\mathrm{E}_{\mathrm{oed}}^{\mathrm{ref}}\right)$, elastic unloading/reloading input parameters $\left(\mathrm{E}_{\mathrm{ur}}^{\mathrm{ref}}, v_{\mathrm{ur}}\right)$ and failure criterion according to the Mohr-Coulomb model (c, $\varphi$ and $\psi$ ).

\subsubsection{Soft Soil Model (SSM)}

The soft soils could be considered like near-normally consolidated clays, clayey silts and peat. A special feature of such materials is their high degree of compressibility. This is best demonstrated by oedometer test data as reported for instance by Janbu in his Rankine lecture (1985). Considering tangent stiffness moduli at a reference oedometer pressure of $100 \mathrm{kPa}$, he reported for normally consolidated clays $\mathrm{E}_{\mathrm{oed}}=1$ to $4 \mathrm{MPa}$, depending on the particular type of clay considered. The differences between these values and stiffnesses for NC-sands are considerable as here the values are in the range of 10 to $50 \mathrm{MPa}$, at least for non-cemented laboratory samples. Hence, in oedometer testing normally consolidated clays behave ten times softer than normally

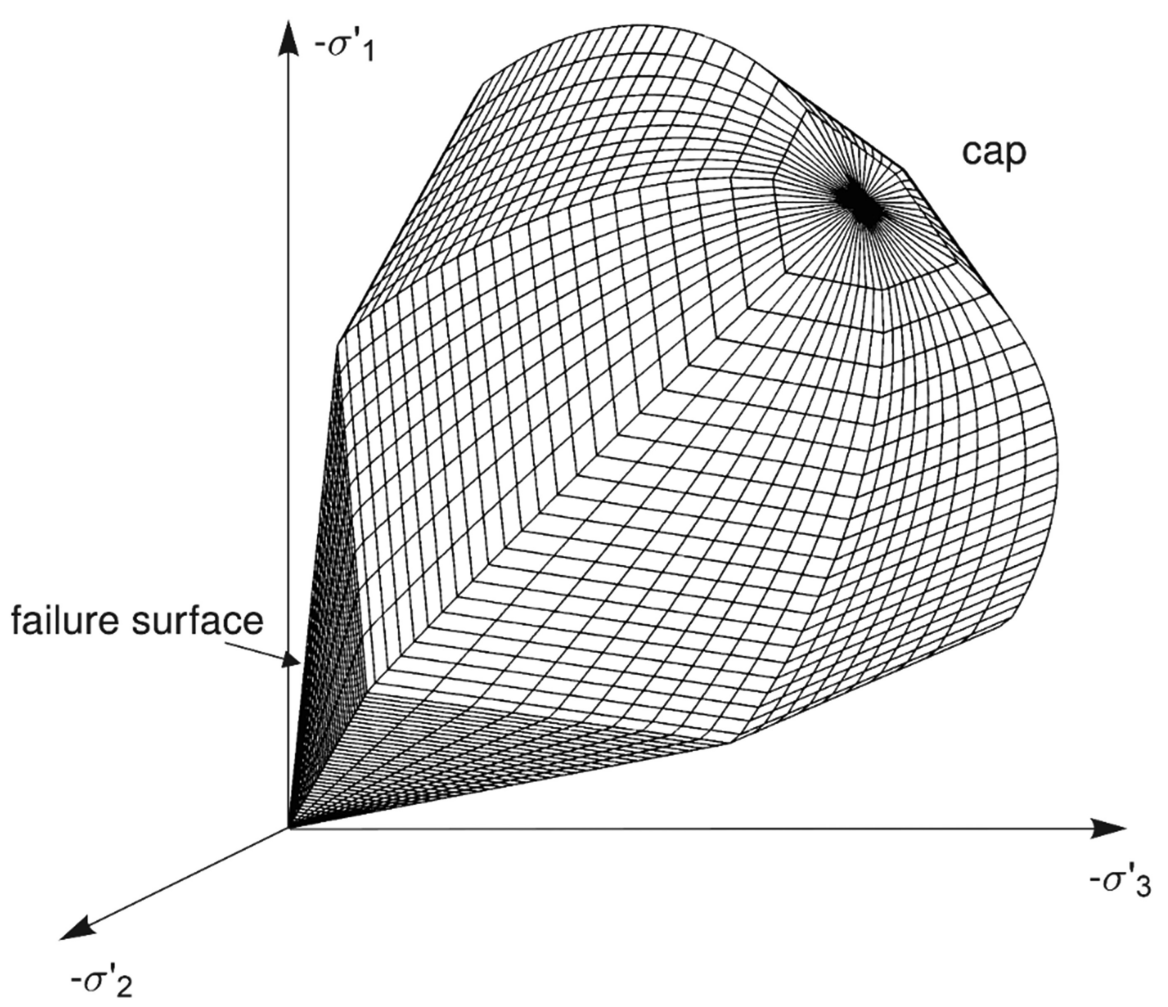

Fig. 3. Total yield contour of the soft-soil constitutive model in principal stress space. 
consolidated sands. This illustrates the extreme compressibility of soft soils. The Soft Soil model is a Cam-Clay type model especially meant for primary compression of near normally consolidated clay-type soils. The total yield contour in principal stress space is shown in Fig. 3. The parameters of the Soft Soil model include compression $\left(\mathrm{C}_{\mathrm{c}}\right)$ and swelling $\left(\mathrm{C}_{\mathrm{s}}\right)$ indicies, which are typical for soft soils, as well as the Mohr-Coulomb model failure parameters.

\subsection{Subsurface Conditions of the Case Studies Site}

The site selected for the field trials at Bothkennar was a facility for large or full scale soft clay researches, with the site having been used extensively for research into in-situ testing and also 'undisturbed' sampling techniques. A comprehensive 'state-of-the-art' ground investigation and geotechnical data existed for the site. A wealth of researches have been previously undertaken, including Hight et al. (1992), Paul et al. (1992) and Nash et al. (1992a, b) and was detailed in the Institution of Civil Engineers Géotechnique Symposium (Vol. 42, No. 2: 1992). The detailed geotechnical profile of the site under study is shown in Fig. 4.

The Bothkennar clay profile shown in Fig. 4, is a result of a well-documented and well-established geotechnical investigation through many research projects. Hight et al. (1992) and Nash et al. (1992a) have provided rigorous investigation works, which had been carried out to provide data characterizing the clay for the benefit of future research projects. The clay properties used in the soil model are presented in Table 1 and are divided into crust, upper Carse clay and lower Carse clay.

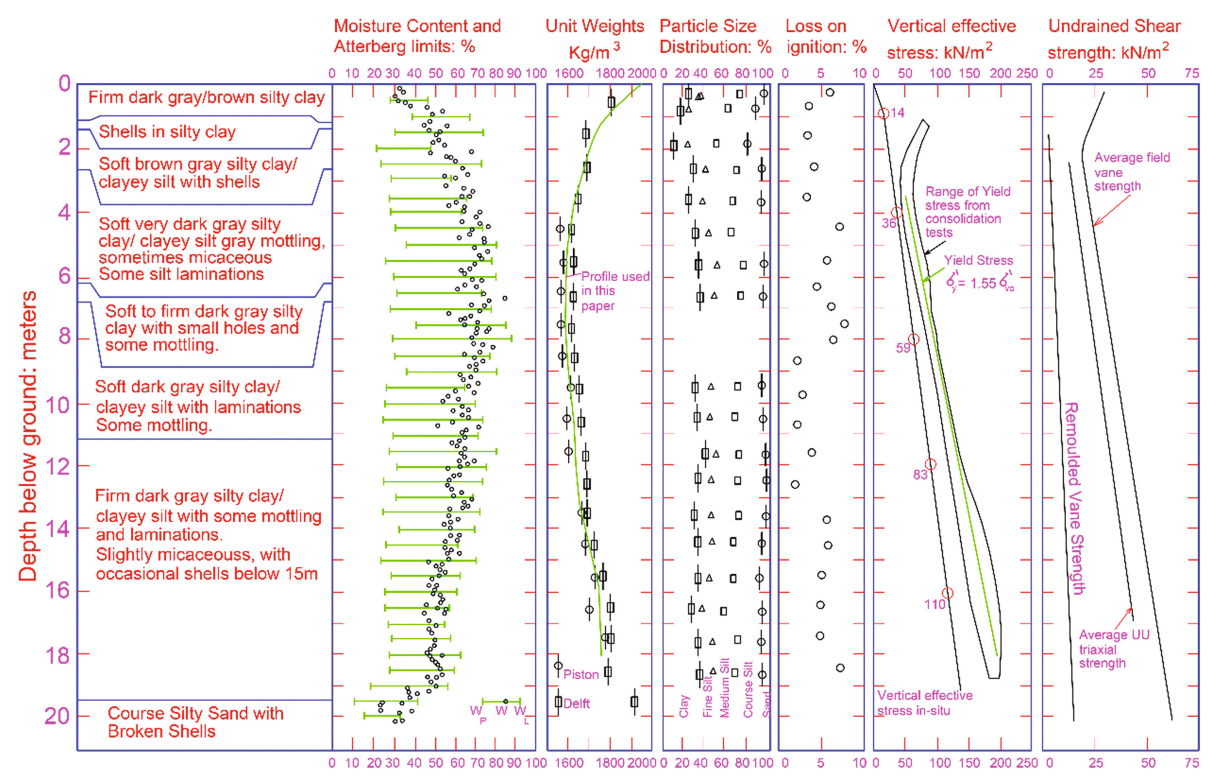

Fig. 4. Key geotechnical profile for the Bothkennar soft clay research site (after Nash et al. $(1992 a, b))$ 
A critical state friction angle $\left(\varphi^{\prime}\right)$ of $34^{\circ}$ is used for the Carse clay. A slightly cohesion value of $3 \mathrm{kPa}$ was used for the crust layers. $\mathrm{E}_{50}^{\text {ref }}$ is assumed equal to $\mathrm{E}_{\text {oed }}^{\text {ref }}$ according to Elshazly et al. (2009).

In choosing the friction angle of the stone backfill, the value of $\varphi^{\prime}=45^{\circ}$ shown in Table 1, in which the stone column properties have been included, should be readily achievable, as noticed by McCabe et al. (2009). Default values of $\mathrm{E}_{50}=70 \mathrm{MPa}$ and $\mathrm{E}_{\mathrm{ur}}=210 \mathrm{MPa}$ were adopted. The exponent, $\mathrm{m}$, for the Hardening Soil model was chosen as $\mathrm{m}=0.3$. These stiffness parameters (i.e. $\mathrm{E}_{50}, \mathrm{E}_{\mathrm{ur}}$ and $\mathrm{m}$ ) are in accordance with the values adopted by Gäb et al. (2008).

Table 1. Summary of the geotechnical material parameters adopted in the analysis of the Bothkennar test site

\begin{tabular}{l|l|l|l|l}
\hline Soil parameter & Crust & $\begin{array}{l}\text { Upper carse } \\
\text { clay }\end{array}$ & $\begin{array}{l}\text { Lower carse } \\
\text { clay }\end{array}$ & $\begin{array}{l}\text { Stone } \\
\text { columns }\end{array}$ \\
\hline Depth $(\mathrm{m})$ & $0.0-1.2: 1.5$ & $1.2: 1.5-2.5$ & $2.5-14.5$ & As needed \\
\hline Bulk unit weight, $\gamma\left(\mathrm{kN} / \mathrm{m}^{3}\right)$ & 18.0 & 16.5 & 16.5 & 19.0 \\
\hline Over-consolidation ratio $(\mathrm{OCR})$ & 1.0 & 1.0 & 1.5 & - \\
\hline Pre-overburden pressure $(\mathrm{kPa})$ & 15 & 15 & 0 & - \\
\hline Coefficient of lateral earth pressure, $\mathrm{K}_{0}$ & 1.5 & 1.0 & 0.75 & 0.3 \\
\hline Effective cohesion, $\mathrm{c}^{\prime}(\mathrm{kPa})$ & 3 & 1 & 1 & 1 \\
\hline Angle of internal friction, $\phi^{\prime}($ degrees $)$ & 34 & 34 & 34 & 45 \\
\hline Dilatancy angle, $\psi($ degrees $)$ & 0 & 0 & 0 & 15 \\
\hline Initial voids ratio, $\mathrm{e}_{0}$ & 1.0 & 1.2 & 2.0 & - \\
\hline Compression index, $\mathrm{C}_{\mathrm{C}}(\mathrm{SSM})$ & 0.07 & 0.25 & 1.12 & - \\
\hline Swelling index, $\mathrm{C}_{\mathrm{S}}(\mathrm{SSM})$ & 0.01 & 0.03 & 0.16 & - \\
\hline $\mathrm{E}_{50}^{\text {ref }}, \mathrm{kPa}(\mathrm{HSM})$ & 1068 & 506 & 231 & 70000 \\
\hline $\mathrm{E}_{\text {ur }}^{\text {ref }}, \mathrm{kPa}(\mathrm{HSM})$ & 5382 & 3036 & 1164 & 210000 \\
\hline $\mathrm{E}_{\mathrm{kPa}(\mathrm{MCM})}$ & 4485 & 2530 & 970.3 & 70000 \\
\hline $\mathrm{m}(\mathrm{HSM})$ & 1.0 & 1.0 & 1.0 & 0.3 \\
\hline Reference pressure, $\mathrm{p}^{\text {ref }}(\mathrm{kPa})$ & 13 & 20 & 30 & 100 \\
\hline $\begin{array}{l}\text { Vertical coefficient of permeability, } \\
\mathrm{k}_{\text {vert }}(\mathrm{m} / \mathrm{day})\end{array}$ & $6.9 \times 10^{-5}$ & $6.9 \times 10^{-5}$ & $6.9 \times 10^{-5}$ & 1.2 \\
\hline $\begin{array}{l}\text { Horizontal coefficient of permeability, } \\
\mathrm{k}_{\text {horz }}(\mathrm{m} / \text { day })\end{array}$ & $1.0 \times 10^{-4}$ & $1.0 \times 10^{-4}$ & $1.0 \times 10^{-4}$ & 1.2 \\
\hline
\end{tabular}

\section{Case Study No (1)}

Instrumented field load test on unreinforced rigid pad footings at the Bothkennar test site, documented by Jardine et al. (1995), is numerically modelled during the scope of this paper. The footing was loaded to failure using kentledge in less than five days, with pauses in loading occurring overnight and whenever the rate of settlement exceeds $8 \mathrm{~mm} / \mathrm{hr}$. The foundation depth of the tested pad is $0.80 \mathrm{~m}$ below ground level, while the square pad side length is $2.20 \mathrm{~m}$. 


\subsubsection{Finite Element Modelling}

The load test is simulated using the software PLAXIS 3D 2016 as an undrained loading (with effective stress material parameters) due to the short duration of the load test. However, the crust in the adopted soil profile is modelled as a drained material as the lower part of the crust contains a significant proportion of shelly fragments (Nash et al. $1992 \mathrm{~b}$ ) and the upper part of the crust is above the groundwater level. A fine mesh has been generated to avoid any effects from the meshing size on the results. Wide boundary conditions have been chosen in order not to affect the settlement response. Figure 5 shows the discretization of the problem.

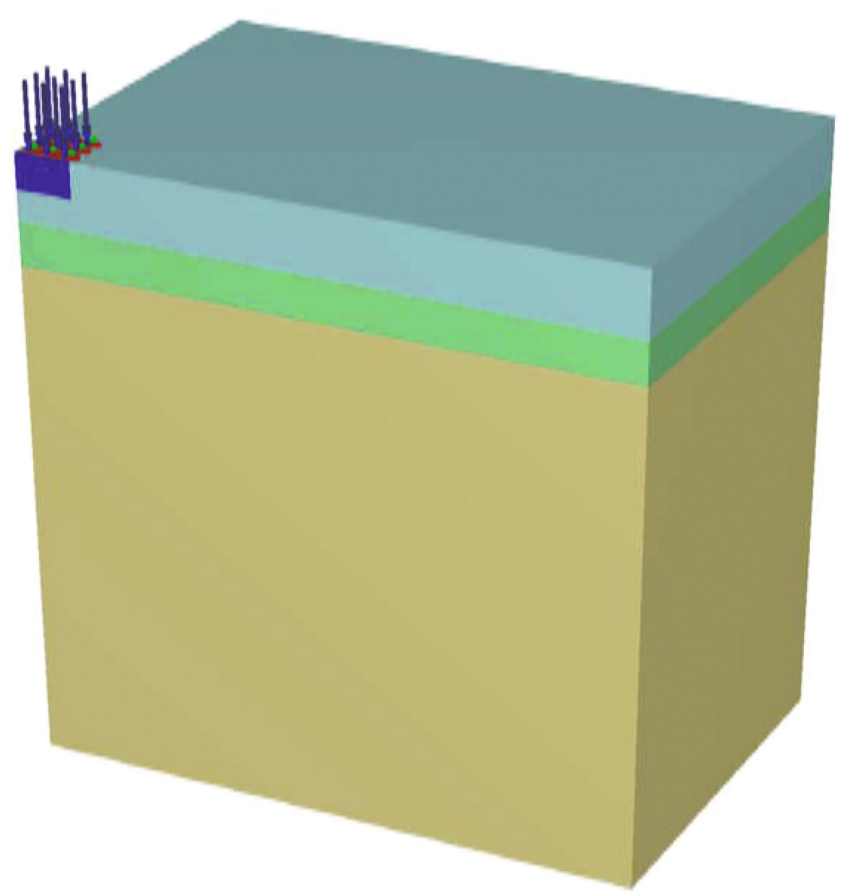

Fig. 5. Finite element model in case study no (1).

\subsubsection{Results and Discussions}

The relations between the load and settlement for both the field measurements and the results of the numerical model using different soil constitutive models are presented in Fig. 6. It can be recognized that the numerical model, in general, using the different constitutive models; (MCM, HSM and SSM), captures the trend of settlement versus applied pressure as compared to the monitored correlation from the field loading test. For the HSM, the settlement predicted value at $140.0 \mathrm{kPa}$, which is the maximum tested stress and represents almost the ultimate bearing pressure as can be understood from the field stress-settlement relation, is almost the same as the field measurement, 


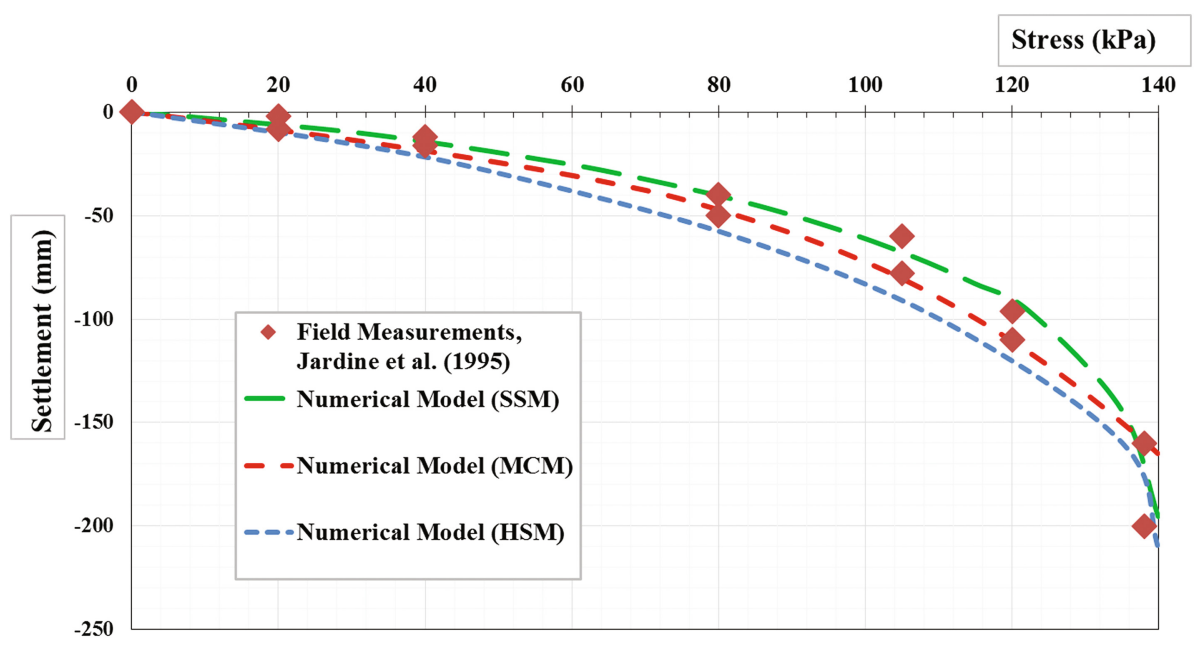

Fig. 6. Comparison between numerical model results using different soil constitutive models and the actual load-displacement behavior for a pad footing.

however there is always a slight over-prediction of the settlement values at any other stress levels. MCM results are generally in a good agreement with the measured settlement values at most stress levels, except at the ultimate stress, $140 \mathrm{kPa}$, where it slightly underestimates the settlement value. The SSM yields acceptable estimate of the settlement values at low stress levels up to about $30 \%$ of the ultimate stress value. Above that level and at higher stress values, the SSM, in general, underestimates the

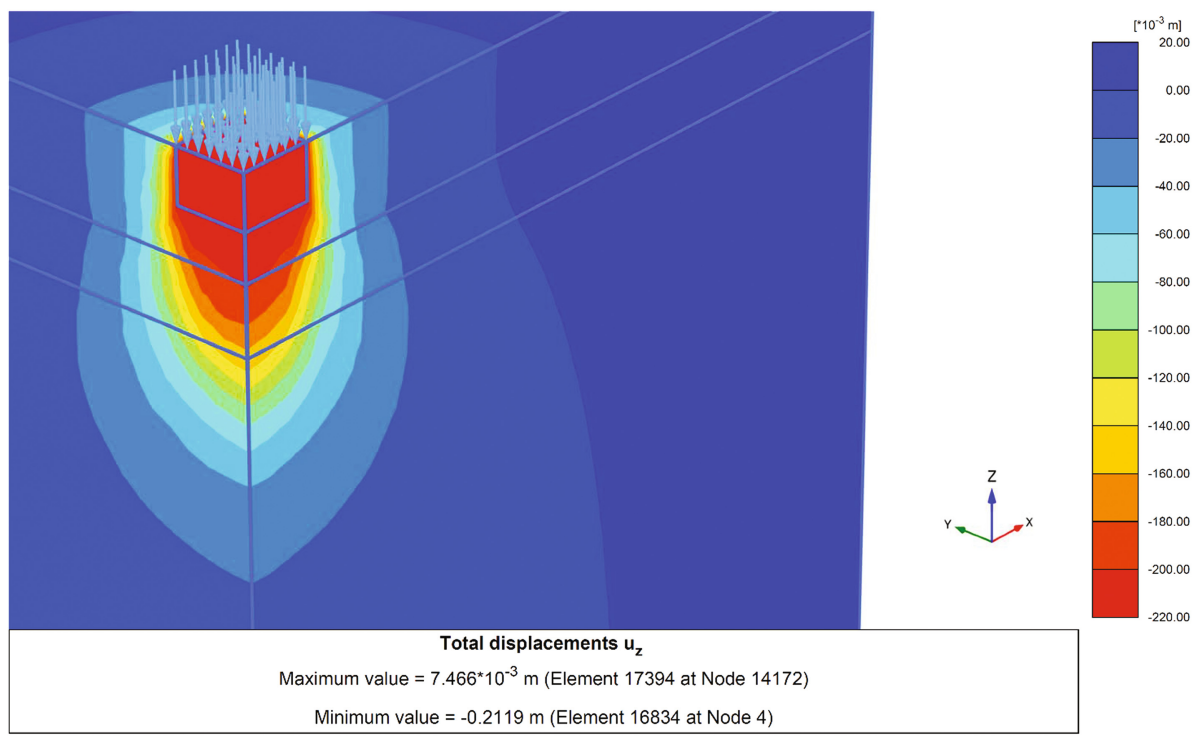

Fig. 7. Displacement field beneath the loaded pad at stress level of $140 \mathrm{kPa}$, using the HSM. 
settlement values of the loaded footings. For this case study, it can be concluded that the three investigated constitutive models can reasonable simulate the actual Bothkennar clay behavior, with the preference to the HSM at high stress levels. Figure 7 presents the total deformations field at an applied stress value of $140 \mathrm{kPa}$ that is almost the ultimate pressure sustained by the loaded pad utilizing the HSM.

\section{Case Study No (2)}

The second case study numerically analyzed in this research is fully detailed by Colin J. Serridge (2013) in his PhD thesis comprising a full-scale field testing of 8 models resting on Bothkennar clay. Eight models were constructed to represent the behavior of the rectangular and square footings in which seven models were resting on a treated soil with small groups of stone columns and one model was loaded without soil improvement. Table 2 summarizes the eight trial footings configurations, while Table 3 provides the loading stages of each model. The first and second loading stages were consolidated in 5 months each.

Table 2. Summary of the trial tests configurations used in case study no (2)

\begin{tabular}{|c|c|c|c|c|c|}
\hline \multirow{2}{*}{$\begin{array}{l}\text { Trial } \\
\text { footing } \\
\text { no. }\end{array}$} & \multirow{2}{*}{$\begin{array}{l}\text { Dimensions } \\
(\mathrm{L} \times \mathrm{B}) \mathrm{m}\end{array}$} & \multirow{2}{*}{$\begin{array}{l}\text { Foundation } \\
\text { depth }(\mathrm{m})\end{array}$} & \multicolumn{3}{|c|}{ Ground treatment } \\
\hline & & & $\begin{array}{l}\text { Number of } \\
\text { stone } \\
\text { columns }\end{array}$ & \begin{tabular}{|l|} 
Stone columns \\
spacing $(\mathrm{m})$
\end{tabular} & $\begin{array}{l}\text { Stone columns lengths } \\
\text { (below footings) } \mathrm{m}\end{array}$ \\
\hline 1 & $6.0 \times 0.75$ & 0.50 & 4 & 1.50 & 5.70 \\
\hline 2 & $6.0 \times 0.75$ & 0.50 & 3 & 2.00 & 5.70 \\
\hline 3 & $3.0 \times 0.75$ & 0.50 & 2 & 1.50 & 3.70 \\
\hline 4 & $3.0 \times 0.75$ & 0.50 & 2 & 1.50 & 5.70 \\
\hline 5 & $3.0 \times 0.75$ & 0.50 & 2 & 1.50 & 7.70 \\
\hline 6 & $3.0 \times 0.75$ & 1.20 & 2 & 1.50 & 5.70 \\
\hline 7 & $1.5 \times 1.5$ & 0.50 & 2 & 1.20 & 5.70 \\
\hline 8 & $3.0 \times 0.75$ & 0.50 & Untreated soil & - & - \\
\hline
\end{tabular}

Table 3. Summary of the loading increments of the trial footings for case study no (2)

\begin{tabular}{l|l|l|l}
\hline $\begin{array}{l}\text { Trial footing } \\
\text { no. }\end{array}$ & $\begin{array}{l}\text { Foundation depth } \\
(\mathrm{m})\end{array}$ & $\begin{array}{l}1^{\text {st }} \text { loading increment } \\
\mathrm{kN} / \mathrm{m}^{2}\end{array}$ & $\begin{array}{l}2^{\text {nd }} \text { loading increment } \\
\mathrm{kN} / \mathrm{m}^{2}\end{array}$ \\
\hline 1 & 0.50 & 35.5 & 72.0 \\
\hline 2 & 0.50 & 32.9 & 67.1 \\
\hline 3 & 0.50 & 33.1 & 67.8 \\
\hline 4 & 0.50 & 34.9 & 71.7 \\
\hline 5 & 0.50 & 32.1 & 67.0 \\
\hline 6 & 1.20 & 34.2 & 69.6 \\
\hline 7 & 0.50 & 32.7 & 67.0 \\
\hline 8 & 0.50 & 34.3 & 71.6 \\
\hline
\end{tabular}




\subsubsection{Finite Element Modelling}

The full-scale models configurations, shown in Table 2, and with the loading stages, summarized in Table 3, have been numerically modeled using PLAXIS 3D 2016. The models represent rectangular as well as square footings configurations. In addition, the foundation depths vary from $0.5 \mathrm{~m}$ to $1.2 \mathrm{~m}$ in order to check whether the crust layer would affect the results or not. The effect of the number of stone columns and the columns spacing ( $\mathrm{S}$ ) have also been investigated through these full-scale field tests. One model (Footing no (8)) has been loaded without adding stone columns, to examine the load-settlement behavior with time for the untreated soil.

\subsubsection{Effect of Constitutive Laws on the Load-Settlement-Time Relationship}

Figure 8 and Table 4 present the load-settlement-time relations pertaining to Footing no (8) for both the field and numerical models. It is noticed that, the MCM can't mimic the behavior of the Bothkennar clay with time especially at the high stress levels and results in underestimated settlement values. On the other hand, the SSM provides a better estimation of the load-settlement relation especially as the duration of loading increases. The error in predicting the settlement, as shown in Table 4, ranges between approximately $(-10 \%)$ and $(-18 \%)$ compared to the error values ranging between approximately $(-25 \%) \&(-40 \%)$ for the MCM. The HSM predicted settlement values are, in general, more close to the field measured deformations with error values ranging between $(-5 \%) \&(+14 \%)$, as can be noticed from Table 4 . Accordingly, it can be concluded that the HSM can represent the load-settlement behavior of the footings founded on the untreated Bothkennar clay in a better manner than both the MCM and the SSM. However, the HSM overestimates the settlement values by $(+10 \%$ to $+14 \%)$ compared to the field results of stress levels above $50 \%$ of the approximate ultimate level.

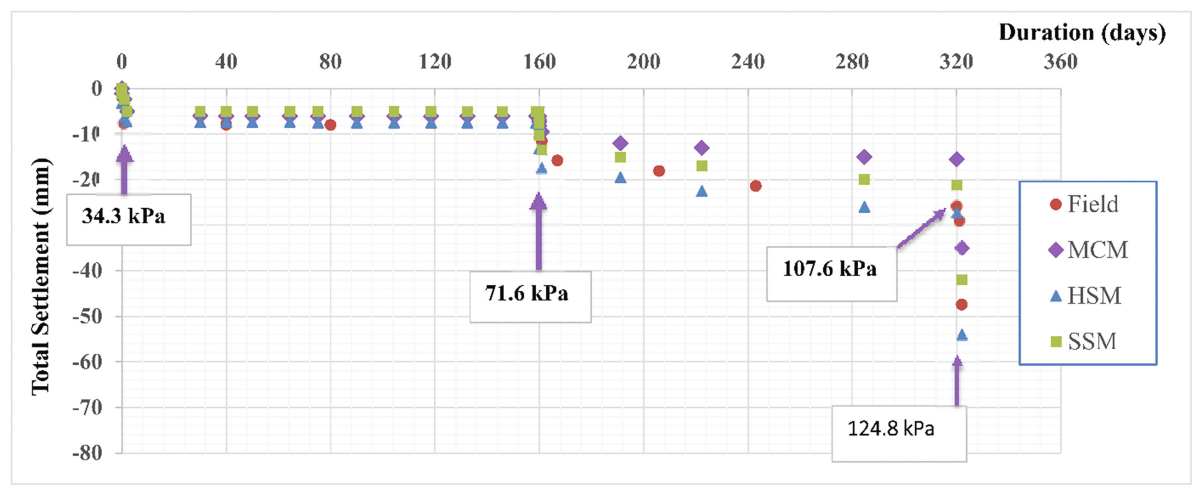

Fig. 8. Measured and predicted load-settlement relations with time for footing no (8) without ground improvement. 
Table 4. Measured and predicted settlement at different stress levels and durations for case study no (2).

\begin{tabular}{|c|c|c|c|c|c|c|c|c|}
\hline \multirow{3}{*}{$\begin{array}{l}\text { Applied } \\
\text { stress } \\
(\mathrm{kPa})\end{array}$} & \multirow{3}{*}{$\begin{array}{l}\text { Time } \\
\text { (day) }\end{array}$} & \multirow{3}{*}{$\begin{array}{l}\text { Measured } \\
\text { settlement } \\
(\mathrm{mm})\end{array}$} & \multicolumn{6}{|c|}{ Numerical model results } \\
\hline & & & \multicolumn{2}{|l|}{$\mathrm{MCM}$} & \multicolumn{2}{|l|}{ SSM } & \multicolumn{2}{|l|}{ HSM } \\
\hline & & & $\begin{array}{l}\text { Estimated } \\
\text { settlement } \\
\text { value } \\
(\mathrm{mm})\end{array}$ & $\begin{array}{l}\text { Error } \\
(\%)\end{array}$ & $\begin{array}{l}\text { Estimated } \\
\text { settlement } \\
\text { alue }(\mathrm{mm})\end{array}$ & $\begin{array}{l}\text { Error } \\
(\%)\end{array}$ & $\begin{array}{l}\text { Estimated } \\
\text { settlement } \\
\text { Value } \\
(\mathrm{mm})\end{array}$ & $\begin{array}{l}\text { Error } \\
(\%)\end{array}$ \\
\hline \multirow[t]{4}{*}{34.3} & 0 & -7.80 & -7.05 & -09.62 & -7.25 & -07.05 & -7.40 & -05.13 \\
\hline & 40 & -7.90 & -7.15 & -09.49 & -7.30 & -07.59 & -7.55 & -04.43 \\
\hline & 120 & -8.00 & -7.25 & -09.38 & -7.40 & -07.50 & -7.80 & -02.50 \\
\hline & 160 & -8.10 & -7.30 & -09.88 & -7.50 & -07.41 & -7.90 & -02.47 \\
\hline \multirow[t]{4}{*}{71.6} & 160 & -15.80 & -9.50 & -39.87 & -13.50 & -14.56 & -17.50 & +10.76 \\
\hline & 220 & -20.40 & -13.20 & -35.29 & -17.15 & -15.93 & -22.50 & +10.29 \\
\hline & 280 & -22.85 & -15.25 & -33.26 & -19.90 & -12.91 & -25.95 & +13.57 \\
\hline & 320 & -25.90 & -15.60 & -39.77 & -21.30 & -17.76 & -27.30 & +05.41 \\
\hline 107.6 & 321 & -29.10 & -20.00 & -31.27 & -25.50 & -12.37 & -32.50 & +11.68 \\
\hline 124.8 & 322 & -47.40 & -35.25 & -25.63 & -42.30 & -10.76 & -54.15 & +14.24 \\
\hline
\end{tabular}

\subsubsection{Effect of the Stone Columns on the Load-Settlement-Time Relations}

The first footing with stone columns (Footing no (1)) was numerically modelled representing a small group of 4 stone columns with spacing of $1.5 \mathrm{~m}$ and length of $5.70 \mathrm{~m}$ with a foundation depth of $0.5 \mathrm{~m}$. The stone columns are modelled using the Mohr Coulomb criterion, while the soil layers were simulated using the three types of soil constitutive models; MCM, HSM and SSM. Figure 9 presents the discretization of the model. Figure 10 shows the relation between the stresses and estimated average settlement with time along with the field measurements. From the results, it can be concluded that both the MCM and SSM constitutive models can't mimic the softy soil behavior properly and results in underestimated predicted values for the settlement

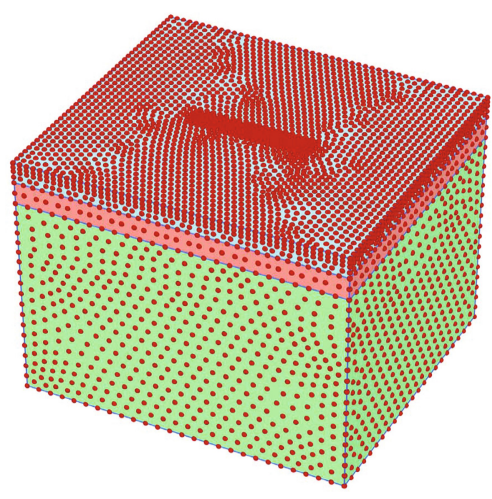

(a) Meshing and nodes.

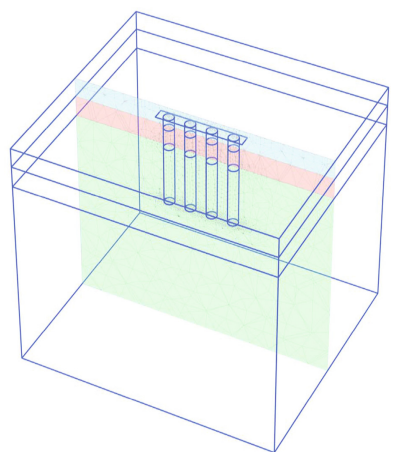

(b) Cross-section to show the stone columns

Fig. 9. Finite element models of footing no (1) for the second case study. 


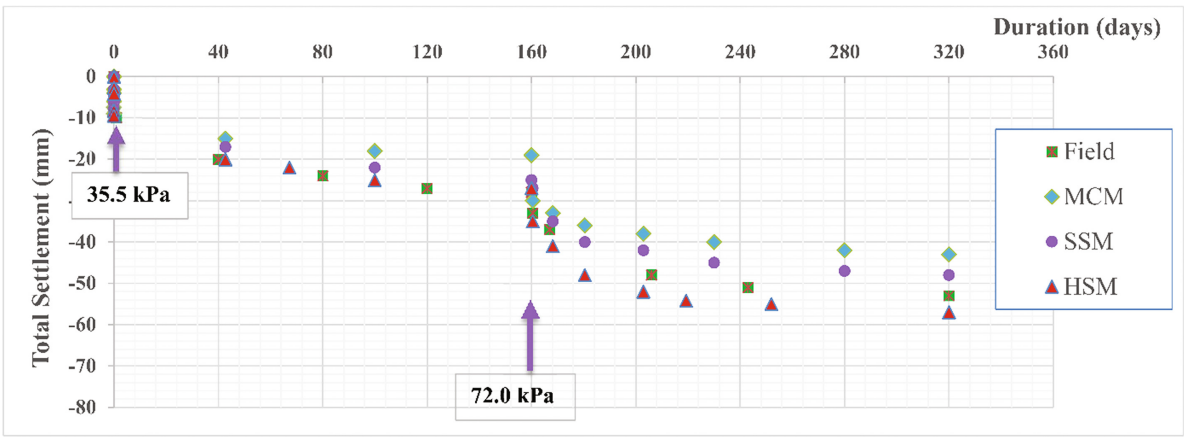

Fig. 10. Measured and predicted load-settlement relations with time for trial footing no (1) of the second case study (footing with four stone columns).

with time. However, all the three soil models could be used at a low stress levels, in which the stress is lower than $30 \%$ of the ultimate bearing pressure. The same as the footing without improvement (Footing 8), the HSM could represent the soil layers of the Bothkennar soil profile, however it results in higher predicted values of settlement in the range of $(+12 \%$ to $+17 \%)$ above the field measurements. Figure 11 shows the deformed shape of the stone columns under an applied stress of $72.0 \mathrm{kPa}$ and using the HSM, in which it can be noticed that bulging partially occurrs with some tilting of the edge columns.

In the light of the previous results, the trial model (Footing 5) was modelled, which represents a different group of only 2 stone columns with the same spacing of $1.5 \mathrm{~m}$

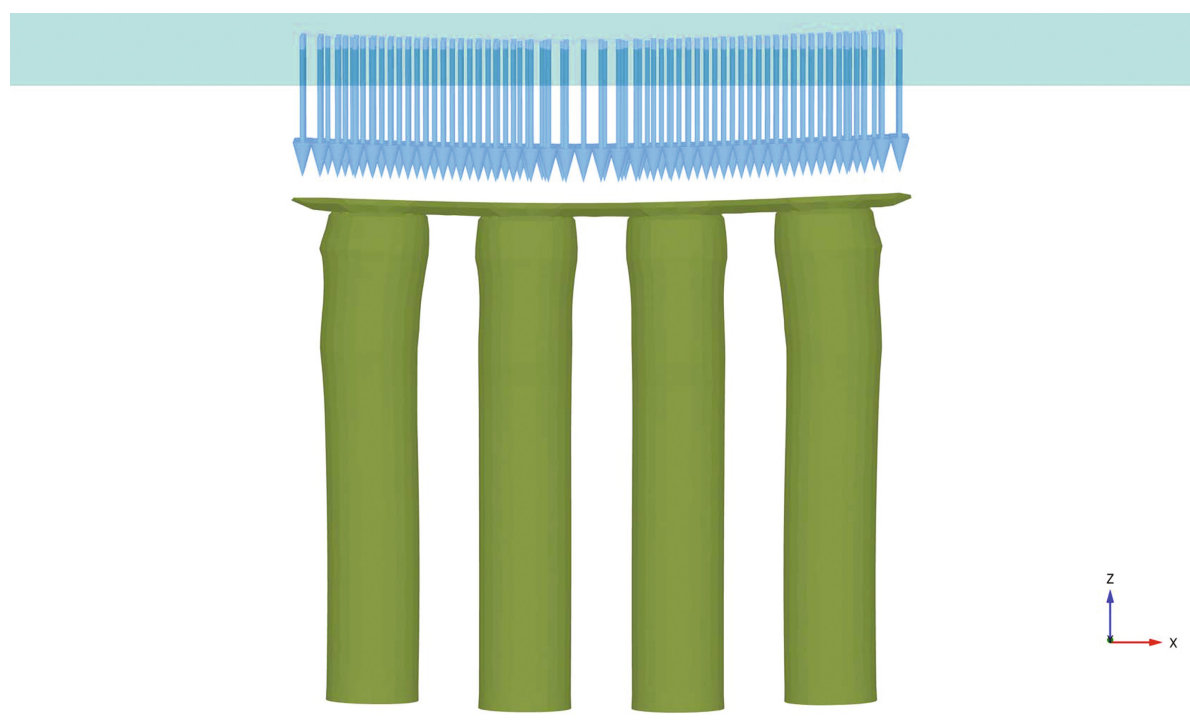

Fig. 11. Deformed shape of the stone columns, for a loading stress of $72.0 \mathrm{kPa}$, using PLAXIS 3D 2016. 
and foundation depth of $0.5 \mathrm{~m}$ but with longer stone columns lengths of $7.7 \mathrm{~m}$. Only the HSM has been adopted to represent the soil layers behavior. Figure 12 shows the relation between the stress and average settlement for both the numerical model and field measurements. It could be noticed that the HSM can represent the loading process, in general, but results in an overestimation of the settlement values by about $(+13 \%$ to $+18 \%$ ) than the field measurements.

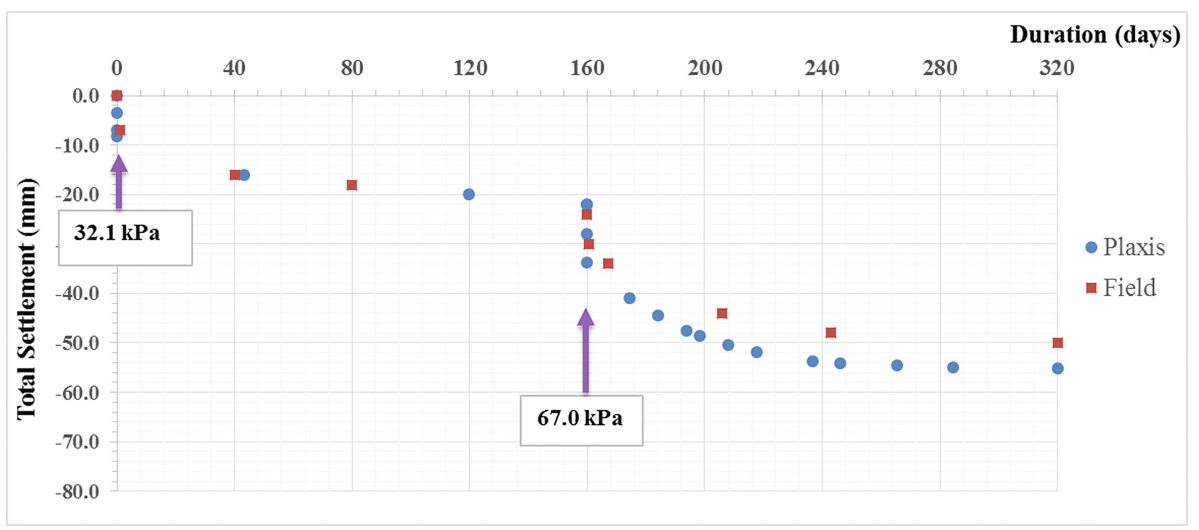

Fig. 12. Measured and predicted load-settlement relations with time for trial footing no (5) of the second case study (footing with two stone columns) utilizing the HSM.

Footing no. (6), as detailed in Table 2, has been also simulated using the same conditions, which represents a different foundation depth of $1.2 \mathrm{~m}$ to rest directly on the upper carse clay, and with using the stone column's spacing of $1.5 \mathrm{~m}$ and length of $5.7 \mathrm{~m}$. The first construction stage was to excavate the overall crust layer, which is $1.2 \mathrm{~m}$ in height, in order to lay the footing directly on the upper carse clay. The second

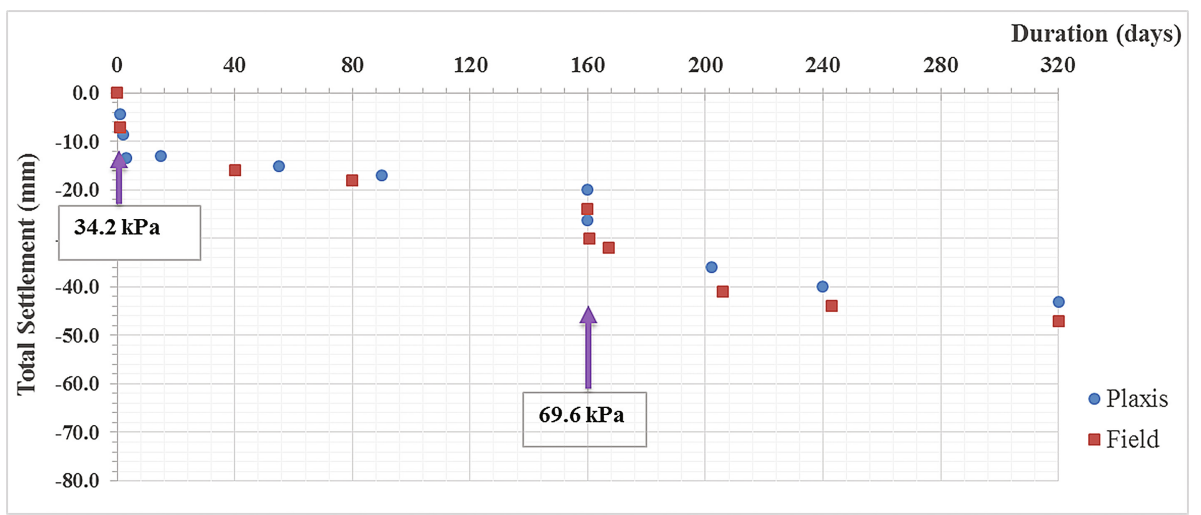

Fig. 13. Measured and predicted load-settlement relations with time for trial footing no (6) of the second case study (footing with two stone columns). 
construction stage was to construct the stone columns and with the configuration given in Table 2. Due to the time duration gap between the two stages, significant heave has been occurred. Figure 13 shows the results of both the numerical model and the field measurements. In this case, and due to the heave resulted from the stages of construction, lower values of the settlement, ranging between $(-5 \%$ to $-9 \%)$, have been predicted using the HSM. However, this range of error is considered still small and would not greatly affect the results. Hence, the HSM could be used to reasonably simulate the behavior of the Bothkennar soil profile in predicting the settlement values.

\section{Conclusions}

This paper presents results of the study of effect of the adopted constitutive models for soft clays behavior simulation on the accuracy of numerical models in predicting the settlement values associated with loading of footings supported on stone columns. The finite element code Plaxis 3D 2016 is used in the performed analyses in which the three common constitutive models; MCM, SSM and HSM, have been used to investigate their suitability in modelling the behavior of the studied soft clay. Two case studies were analyzed in which the first case was for a short term loading of a footing founded on the Bothkennar clay without ground improvement. The second case study included modelling of several trial footings with and without ground improvement and with different configurations of the stone columns for the ground treated cases. The performed analyses showed that the three investigated constitutive models can capture the stress-settlement behavior of the Bothkennar soft clay with the preference of the HSM over other models especially for the long term loading conditions. Using the HSM resulted in predicting the settlement values associated with loading footings supported on stone columns in the Bothkennar soft clay with an approximate deviation in the accuracy ranging between $(-9 \%$ to $+20 \%)$ compared with the actual field measured values. Both the MCM and SSM can be used in simulating the behavior of the studied clay formation but with less accuracy ranging between approximately ( $-25 \%$ to $-40 \%)$ and $(-10 \%$ to $-18 \%)$, simultaneously.

\section{References}

Black, J.A.: The settlement performance of a footing supported on soft clay reinforced with vibrated stone columns. Ph.D. thesis, Queen's University of Belfast (2006)

Brinkgreve, R.B.J., Vermeer, P.A.: Plaxis Finite Element Code for Soil and Rock Analysis-Version 7. Balkema, Rotterdam (1997)

Brinkgreve, R.B.J.: Selection of soil models and parameters for geotechnical engineering application. In: Yamamuro, J.A., Kaliakin, V.N., (eds.) Geotechnical Special Publication No. 128, ACSE, pp. 69-98 (2005)

Serridge, C.J.: An evaluation of partial depth dry bottom-feed vibro stone columns to support shallow footings in deep soft clay deposits. Ph.D. thesis, Anglia Ruskin University, UK (2013) 
Elshazly, H.A., Hafez, D.H., Mossaad, M.E.: Reliability of conventional settlement evaluation for circular foundations on stone columns. Geotech. Geol. Eng. 26(3), 323-334 (2009)

Gäb, M., Schweiger, H.F., Kamrat-Pietraszewska, D., Karstunen, M.: Numerical analysis of a floating stone column foundation using different constitutive models. In: Proceedings of the 2nd International Workshop on Geotechnics of Soft Soils, Glasgow, pp. 137-142 (2008)

Hight, D.W., Bond, A.J., Legge, J.D.: Characterisation of the Bothkennar clay: an overview. Geotechnique 42(2), 303-347 (1992)

Institution of Civil Engineers: Bothkennar soft clay test site: characterization and lessons learned. Geotechnique 42(2), 161-378 (1992)

Jardine, R.J., Lehane, B.M., Smith, P.R., Gildea, P.A.: Vertical loading experiments on rigid pad foundations at Bothkennar. Geotechnique 45(4), 573-597 (1995)

McCabe, B.A., Nimmons, G.J., Egan, D.: A review of field performance of stone columns in soft soils. In: Proceedings of ICE Geotechnical Engineering (2009)

Nash, D.F.T., Sills, G.C., Davison, L.R.: Onedimensional consolidation testing of soft clay from Bothkennar. Geotechnique 42(2), 241-256 (1992a)

Nash, D.F.T., Powell, J.J.M., Lloyd, I.M.: Initial investigations of the soft clay site at Bothkennar. Geotechnique 42(2), 163-181 (1992b)

Paul, M.A., Peacock, J.D., Wood, B.F.: The engineering geology of the Carse clay of the national soft clay research site. Bothkennar. Géotechnique 42(2), 183-198 (1992)

Schanz, T.: Zur modellierung des mechanishen verhaltens von reibungsmaterialen. Habilitation. Stuttgard University (1998) 